\title{
SKRINING AKTIVITAS ANTIBAKTERI DAUN KELOR (Moringa oleifera), DAUN BIDARA LAUT (Strychnos ligustrina Blume), DAN AMOXICILIN TERHADAP BAKTERI PATOGEN Staphylococcus aureus
}

\author{
Edi Suriaman $^{1 *}$, Solikhatul Khasanah ${ }^{2}$ \\ ${ }^{1}$ Dosen Prodi D III Analis Kesehatan, Akademi Analis Kesehatan Malang, \\ ${ }^{2}$ Mahasiswa Prodi D III Analis Kesehatan, Akademi Analis Kesehatan Malang \\ *E-mail : suriamans@gmail.com
}

\begin{abstract}
Exploration of a variety of plants as a source of antibacterial has been made to identify newer components, but not all plants effective to inhibit the growth of bacteria. This study aims to determine the difference between the ability of the antibacterial activity of plant leaves Moringa oleifera, Strychnos ligustrina Blume, and amoxicilin against Staphylococcus aureus bacteria growth. This study an experiment in complete random factorial design with three factors and four levels with four replicates. Testing the antibacterial activity performed on MuellerHinton agar media with the diffusion method. The analysis and interpretation of results by ANOVA 95\% ( $\alpha$ : 0.05). Susceptibility bacteria to antibiotics, and plant extracts assessed according to standard NCCLS (National Committee for Clinical Laboratory Standards). The antibacterial agent (ethanol extract of Moringa leaf, ethanol extract of $S$. ligustrina leaf, and amoxicillin), and concentrations influence significantly inhibit the growth of $S$. aureus bacteria. $S$. aureus bacteria represent sensitive only at $100 \%$ concentration with inhibition zone diameter $21.5 \pm 5: 35 \mathrm{~mm}$, and at a concentration of $75 \%$ with a diameter of $14.3 \pm 1.32 \mathrm{~mm}$ represent intermediate, when apply the leaf extract of $S$. ligustrina. The bacteria behave-resistant to the compound of $M$. oleifera leaf extract and amoxicillin at all concentrations. Diameter of zones of inhibition amoxicillin equal $9.99 \pm 2.02 \mathrm{~mm}$ with $100 \%$ concentration treatment. While the treatment of M. oleifera leaf extract, at a concentration of $75 \%$ and $100 \%$, resulting in the largest inhibition zone each $3.9 \pm 0.64$ and $3.82 \pm 0.57 \mathrm{~mm}$.
\end{abstract}

Keywords: Antibakteri; Moringa oleifera; Strychnos ligustrina; Staphylococcus aureus.

\section{PENDAHULUAN}

Saat ini, telah terjadi peningkatan prevalensi organisme patogenik yang resisten terhadap berbagai antibiotik, sehingga suseptibilitas berbagai strain bakteri infeksius menjadi berkurang (Rahman et al, 2009). Staphylococcus aureus adalah salah satu patogen penting yang berasosiasi dengan kesehatan, dan banyak studi yang memperlihatkan infeksi nosokomial S. aureus, khsusunya bloodstream infeksi (Kim et al, 2014). Hasil penelitian Nair et al (2013), memperlihatkan bahwa kira-kira $28 \%$ strain jenis $S$. aureus menunjukan sifat resisten terhadap berbagai jenis antibiotik.

Transmisi S. aureus terjadi melalui infeksi kulit atau kontak secara terus menerus pada permukaan seperti tangkai pintu, bangku, handuk dan kran air (Khan et al., 2015). S. aureus ini merupakan tipikal bakteri yang menyebabkan infeksi kulit dan jaringan lunak, tetapi juga dapat menyebabkan infeksi invasif seperti bakteremia, sepsis, endocarditis, pneumonia, maupun osteomyelitis (Nair et al., 2013). Uwaezuoke dan Aririatu (2004), juga melaporkan bahwa $95.8 \% \mathrm{~S}$. aureus resisten terhadap penicillin, sekitar $89.6 \%$ resisten terhadap ampicillin, dan $87.5 \%$ resisten terhadap tetracycline.

Melihat kondisi ini, tentu menjadi hal yang sangat urgen untuk mencari strategi baru untuk melawan infeksi yang di sebabkan oleh berbagai bakteri. Senyawa antimikroba pada tanaman telah di investigasi melalui sejumlah studi di seluruh dunia, dan banyak diantaranya yang digunakan sebagai sebagai alternatif pengobatan. Senyawa antimikroba pada tanaman merupakan merupakan hasil metabolit sekunder, senyawa ini terdiri dari alkaloid, fenol, dan lain-lain (Rahman et al, 2009).

Beberapa tanaman yang sudah banyak di eksplorasi sebagai senyawa antibakterial adalah tanaman kelor, tanaman ini merupakan famili Moringaceae, dan termasuk tanaman asli di India, Pakistan, Bangladesh, dan Afghanistan yang sebagian besar digunakan untuk treatmen infeksi bakteri, infeksi fungi, penyaki menular seksual, antiinflammasi, malnutrisi dan diare. Serta tanaman ini telah digunakan sebagai sumber obat rakyat (Rahman et al, 2009). Shailemo et al (2016), melaporkan bahwa ekstrak $M$. oleifera memiliki aktifitas 
antibakterial melawan Bacillus cereus, Enterococcus faecalis dan Escherichia coli, dengan zona hambat antara $7-9 \mathrm{~mm}$, pada konsentrasi $50 \mathrm{mg} / \mathrm{mL}$.

Selain itu, beberapa jenis tanaman asli Indonesia juga masih belum banyak di eksplorasi kemampuannya dalam melawan pertumbuhan bakteri, salah satunya tanaman bidara laut (Strychnos ligustrina), padahal di masyarakat sudah banyak memanfaatkannya sebagai sumber bahan obat untuk infeksi. Tanaman ini merupakan tanaman endemik Indoensia yang berada di Bima dalam bahasan Bima di sebut Songga. Persebarannya Bali dan Nusa Tenggara. Beberapa hasil penelitian menunjukan bahwa tanaman ini diketahui memiliki kandungan fitokimia seperti tannin, flavonoid, fenol, alkaloid maupun saponin (Setiawan et al., 2014; Sudhira et al, 2015). Hasil studi Mahalingam (2011), dan Sudhira et al (2015), melaporkan dua jenis spesies dari Genus Strychnos juga memiliki aktivitas antibakteria yaitu $S$. nuxvomica dan S. colubrina. Berdasarkan hal ini, maka perlu dilakukan pengujian untuk membandingkan kemampuan antibakteri pada berbagai tanaman. Sehingga diperlukan sebuah penelitian yang membandingkan kemampuan tanaman sebagai sumber senyawa antibakteri.

\section{METODOLOGI PENELITIAN}

\section{a. Waktu dan Tempat}

Penelitian ini dilakukan di laboratorium Bakteriologi, Akademi Analis Kesehatan Malang pada tanggal 15 Mei sampai dengan 30 Juni 2016. Sampel daun kelor $(M$. oleifera) dan daun bidara laut (S. ligustrina Blume) di peroleh dari Bima, NTB.

\section{b. Alat dan Bahan}

Alat-alat yang digunakan antara lain: cawan petri, timbangan analitik, autoklaf, labu erlenmeyer, tabung reaksi, jangka sorong, inkubator, batang pengaduk, bunsen, swab, membran filter, kertas label, aluminium foil, masker, handscoon, pipet ukur, filer, pinset, dan gelas ukur.

Bahan-bahan yang digunakan antara lain: biakan bakteri Staphylococcus aureus, ekstrak daun bidara laut, ekstrak daun kelor, aquades steril, paper disc, dan $\mathrm{NaCl}$ 0,9\%, Mueller Hinton Agar (MHA), dan larutan Mc. Farland.

\section{c. Rancangan Penelitian}

Penelitian ini merupakan penelitian eksperimental dengan menggunakan Rancangan Acak Lengkap (RAL) faktorial 3X4 dengan 4 kali ulangan. Faktor I adalah jenis tanaman (ekstrak daun Kelor, ekstrak daun Bidara Laut dan amoxicilin), dan faktor II adalah konsentrasi $(25 \%, 50 \%, 75 \%$, dan $100 \%)$.

\section{d. Pembuatan Ekstrak Etanol Daun Kelor dan Bidara Laut}

Pembuatan ekstrak etanol tanaman berdasarkan metode Poongothai dan Rajan (2013), dan Suriaman et al (2016) yang dimodifikasi. Bahan daun kelor dan bidara laut sebanyak 500 gr yang dipeti kemudian di buat menjadi simplisia dengan cara melakukan pengeringan dibawah sinar matahari. Daun yang telah kering digiling hingga halus. Kemudian maserasi dengan menggunakan etanol 96\%. Kemudian hasil disaring dan dievaporasi dalam rotary evaporator untuk menghasilkan ekstrak yang di buat sebagai bahan uji.

\section{e. Uji Aktivitas Antibakteri}

Pengujian dilakukan dengan metode Poongothai dan Rajan (2013). Aktivitas antibakteri ekstrak etanol daun kelor dan bidara laut dilakukan pada media Mueller-Hinton agar dengan metode difusi. Inokulum di sebar diatas permukaan media melalui swab dalam tiga arah menggunakan kapas lidi swab. Inokulat kemudian di biarkan mengering selama 10 menit sebelum meletakkan disk. Kemudian paper disk seteril direndam dalam berbagai konsentrasi ekstrak, dan amoxicilin yaitu 25\%, 50\%, $75 \%$, dan $100 \%$. Amoxicillin di gunakan sebagai bahan pembanding untuk mengetahui kemampuan kepekaan S. aureus terhadap antibiotik. Paper disk diletakkan di atas permukaan agar dan diatur jaraknya sedemikian rupa agar zona hambat tidak tumpang tindih. Cawan di tempatkan pada suhu ruang selama 30 menit (waktu pra difusi), kemudian dibalikkan dan diinkubasi pada suhu $37^{\circ} \mathrm{C}$ selama 24 jam. Pembacaan zona hambat dilakukan dengan menggunakan jangka sorong dengan satuan millimeter. Disk yang rendam dalam aquades steril digunakan sebagai kontrol negatif dan disk yang direndam dalam amoxicillin digunakan sebagai kontrol positif.

\section{f. Analisa Data}

Analisa penelitian ini dilakukan dengan menggunakan analisis statistik yaitu uji One Way ANOVA. Jika terdapat perbedaan yang signifikan maka dilakukan uji lanjut menggunakan Duncan pada taraf signifikan 95\% $(\alpha: 0,05)$. Untuk membandingkan kemampuan kepekaan antibiotik dengan ekstrak etanol daun kelor dan bidara laut maka dianalisa secara deskriptif yang digolongkan kedalam tiga kriteria sesuai dengan NCCLS (National Committee for Clinical Laboratory Standards) (Faisal et al, 2015).

\section{HASIL DAN PEMBAHASAN A. Hasil}

Berdasarkan hasil analisa data dengan menggunakan ANOVA (Tabel 1), bahwa perlakuan 2 
ekstrak tanaman dan amoxicillin berpengaruh sangat nyata terhadap penghambatan pertumbuhan $S$. aureus ( $p<$ 0.05). Pada analisa konsentrasi perlakuan menunjukkan adanya perbedaan yang signifikan dalam menghambat pertumbuhan $S$. aureus $(\mathrm{p}<0.05)$. Sedangkan perlakuan dan konsentrasi juga menunjukkan adanya interaksi yang sangat nyata dalam menghamabat pertumbuhan pertumbuhan $S$. aureus ( $\mathrm{p}<$ 0.05) (Tabel 1). Penghambatan pertumbuhan bakteri di tunjukkan dengan adanya zona hambat.
Hasil uj lanjut juga memperlihatkan bahwa ekstrak etanol daun bidara laut ( $S$. ligustrina) memiliki kemampuan yang lebih baik dalam menghambat pertumbuhan bakteri $S$. aureus dibandingkan dengan ekstrak etanol daun kelor $(M$. oleifera) dan amoxicillin. Sedangkan hasil uji lanjut konsentrasi perlakuan memperlihatkan bahwa konsentrasi $100 \%$ efektif menghambat pertumbuhan bakteri patogen $S$. aureus dibandingkan dengan konsentrasi lainnya.

Tabel 1. Hasil ANOVA aktivitas Antibakteri Daun Kelor (Moringa oleifera), Bidara Laut (Strychnos ligustrina Blume), dan Amoxicilin terhadap Bakteri Patogen Staphylococcus aureus

\begin{tabular}{cccccc}
\hline Source & Type III Sum of Squares & df & Mean Square & F & Sig. \\
\hline Ekstrak & 555.388 & 2 & 277.694 & 57.843 & .000 \\
Konsentrasi & 542.190 & 3 & 180.730 & 37.646 & .000 \\
Ekstrak * Konsentrasi & 362.477 & 6 & 60.413 & 12.584 & .000 \\
Error & 158.427 & 33 & 4.801 & & \\
Total & 3894.497 & 48 & & & \\
\hline
\end{tabular}

Kepekaan S. aureus terhadap ekstrak etanol daun S. ligustrina, ekstrak etanol daun $M$. oleifera dan amoxicillin memberikan respon yang berbeda (Tabel 2). Bakteri S. aureus bersifat resisten pada semua konsentrasi ekstrak etanol daun $M$. oleifera dan amoxicillin. Diameter zona hambat terbesar amoxicillin adalah 9.99 $\pm 2.02 \mathrm{~mm}$ dengan konsentrasi perlakuan $100 \%$. Sedangkan pada konsentrasi $75 \%$, diameter terbesar yaitu $6.3 \pm 1.21 \mathrm{~mm}$. Pada perlakuan ekstrak etanol daun $M$. oleifera, pada konsentrasi $100 \%$, diameter zona hambat yang dihasilkan sebesar $3.82 \pm 0.57 \mathrm{~mm}$, pada konsentrasi $25 \%, 50 \%$ dan $75 \%$, masing-masing diameter yang dihasilkan adalah $3.05 \pm 0.82,3.28 \pm 0.67$, dan $3.9 \pm 0.64 \mathrm{~mm}$.

Pada perlakuan ekstrak daun $S$. ligustrina, bakteri $S$. aureus hanya bersifat sensitif pada konsentrasi $100 \%$ dengan diameter zona hambat $21.5 \pm 5.35 \mathrm{~mm}$, pada konsentrasi $75 \%$ dengan nilai diameter $14.3 \pm 1.32 \mathrm{~mm}$, bakteri $S$. aureus bersifat Intermediate. Pada konsentrasi $25 \%$ dan $50 \%$, bakteri $S$. aureus bersifat resisten dengan nilai diameter zona hambat masing-masing $5.98 \pm 3.83$ dan $4.31 \pm 1.94 \mathrm{~mm}$. Sedangkan hasil kontrol negatif tidak menunjukkan adanya zona hambat selama uji berlamgsung.

Tabel 2. Interpertasi kepekaan $S$. aureus terhadap Ekstrak etanol daun S. ligustrina, Ekstrak etanol daun M. oleifera dan amoxicillin kriteria NCCLS.

\begin{tabular}{lccl}
\hline Perlakuan & Diamater (mm) & Interpretasi \\
\hline Ekstrak daun S. ligustrina & $25 \%$ & $5.98 \pm 3.83$ & Resisten \\
& $50 \%$ & $4.31 \pm 1.94$ & Resisten \\
& $75 \%$ & $14.3 \pm 1.32$ & Intermediate \\
Ekstrak daun M. oleifera & $100 \%$ & $21.5 \pm 5.35$ & Sensitif \\
& $25 \%$ & $3.05 \pm 0.82$ & Resisten \\
& $50 \%$ & $3.28 \pm 0.67$ & Resisten \\
Amoxicilin & $75 \%$ & $3.9 \pm 0.64$ & Resisten \\
& $100 \%$ & $3.82 \pm 0.57$ & Resisten \\
& $25 \%$ & $2.15 \pm 0.22$ & Resisten \\
& $50 \%$ & $3.78 \pm 1.16$ & Resisten \\
& $75 \%$ & $6.3 \pm 1.21$ & Resisten \\
& $100 \%$ & $9.99 \pm 2.02$ & Resisten \\
\hline
\end{tabular}




\section{B. Pembahasan}

Potensi antibakterial yang terdapat pada bahan ekstrak dan antibiotik mengindikasikan bahwa pertumbuhan bakteri dapat dicegah. Pada media agar uji, ekspansi koloni bakteri akan di halangi oleh senyawa yang terdapat pada bahan uji atau perlakuan. Setelah diinkubasi, zona hambat akan teridentifikasi dari adanya area transparan. Area ini menunjukkan bahwa tidak adanya koloni bakteri (Ariza et al, 2014).

Pada penelitian ini, untuk kontrol negatif digunakan aquades stertil (data tidak di perlihatkan). Aquades steril tidak menunjukkan aktivitas antibakteri. Hal ini disebabkan aquades tidak memiliki senyawa antimikroba yang dapat menghambat pertumbuan bakteri $S$. aureus. Berdasarkan kriteria yang dikembangkan oleh NCCLS (National Committee for Clinical Laboratory Standards), kepekaan bakteri jika dibandingkan dengan standar amoksisilin adalah resisten (R) jika luas zona hambatan 0-13 mm, intermediate (I) jika luas zona hambatan 14-17 mm, dan sensitif (S) jika luas zona hambatan diatas $18 \mathrm{~mm}$ (Faisal et al, 2015).

Bakteri bersifat resisten berarti adanya kegagalan senyawa pada tanaman atau antibiotik dalam menghambat pertumbuhan bakteri. Bakteri bersifat sensitifitas berarti antibiotik atau senyawa antibakteri bekerja baik dan sukses dalam menghambat pertumbuhan bakteri. Sedangkan intermediat menunjukkan bahwa pengaruh senyawa yang terdapat pada bahan perlakuan memperlihatkan efek yang samar atau tidak menentu, apakah bersifat sensitif atau resisten (Rodloff et al, 2008).

Bakteri S. aureus merupakan patogen yang sangat penting. Bakteri ini berbentuk coccus bergrampositif, tidak membentuk non-spora, katalase dan koagulasi positif, dan bersifat anaerob fakultatif (Khan et al., 2015). Berdasarkan tabel 2, bakteri ini bersifat resisten terhadap senyawa pada ekstrak daun M. oleifera dan amoxicillin pada semua konsentrasi. Sedangkan pada ekstrak daun S. ligustrina, bakteri tersebut hanya resisten pada konsentrasi ekstrak $25 \%$ dan 50\%. Menurut Nazzaro et al (2013), kemampuan dan efek antibakteri sangat tergantung pada konsentrasi yang diberikan. Selain itu Reygaert (2016), menyatakan bahwa sebagian besar sel bakteri memiliki banyak komponen yang potensial sebagai target senyawa agen antimikroba; akan tetapi beberapa bakteri dapat memodifikasi semua sel target untuk dapat bersifat resisten terhadap suatu senyawa atau antibiotik. Selain itu $S$. aureus memiliki kemampuan untuk memproduksi dinding sel yang tebal, sehingga membuat agen antimikroba sulit untuk masuk ke dalam sel.
Pada ekstrak daun S. ligustrina, konsentrasi $75 \%$ dan $100 \%$, bakteri S. aureus bersifat intermediate dan sensitif. Beberapa studi melaporkan adanya aktivitas antibakteri berbagai senyawa seperti fenol dan senyawa turunan lainnya. Mekanisme aktivitas bakteriosidal suatu senyawa terjadi melalui beberapa cara termasuk mengganggu proses metabolisme sel bakteri, menghambat sintesis dinding sel, merusak permeabilitas membran sel, dan mengganggu ekspresi asam nukleat dan gen bakteri (Ariza et al, 2014). Hasil laporan lainnya menyatakan bahwa tanaman yang memiliki senyawa esensial seperti fenol bersifat antibakteria (Nazzaro et al, 2013). Sehingga tanaman S. ligustrina yang digunakan dalam penelitian ini dapat dianggap memiliki kandungan senyawa yang potensial untuk dikembangakan sebagai bahan antibakterial melawan bakteri gram positif seperti $S$. aureus, berdasarkan luas zona hambat yang muncul terutama pada konsentrasi $100 \%$. Menurut Nazzaro et al (2013), kemampuan senyawa antibakteri pada konsentrasi rendah, mempengaruhi produksi energi bakteri. Sedang pada konsentrasi tinggi dapat mendenaturasi protein.

Perbedaan jenis tanaman juga menjadi faktor penentu aktivitas antibakteri suatu tanaman. Hal inilah yang membedakan kemampuan daun $S$. ligustrina dalam menghambat pertumbuhan bakteri $S$. aureus lebih baik dari pada daun $M$. oleifera. Suriaman et al (2016), menyatakan bahwa kondisi pertumbuhan tanaman seperti musim, temperature, kadar alkali, serta salinitas dapat mempengaruhi respon akumulasi senyawa tanaman melalui sistem metabolik, yang dapat menentukan konsentrasi berbagai senyawa sekunder dalam tanaman

\section{KESIMPULAN}

Ekstrak etanol daun bidara laut (S. ligustrina) memperlihatkan aktivitas antibakteri yang lebih baik di bandingkan $M$. oleifera dan amoxicillin. Daun $S$. ligustrina bekerja baik dalam menghambat $S$. aureus.

\section{DAFTAR PUSTAKA}

[1] Ariza, B.T.S., D.C. Mufida., N.N. Fatima., T.I. Hendrayati., T. Wahyudi., and Misnawi. 2014. In Vitro Antibacterial Activity of Cocoa Ethanolic Extract Against Escherichia coli. International Food Research Journal. 21(3): 935-940.

[2] Faisal, M., Fatimawali., Wewengkang, D.S. 2015. Uji Kepekaan Bakteri yang Diisolasi dan Diidentifikasi dari Sputum Penderita Bronkhitis di RSUP Prof dr. R. D. Kandou Manado terhadap Antibiotik Golongan Sefalosporin (Sefiksim), Penisilin (Amoksisilin) dan 
Jurnal Biota Vol. 3 No. 1 Edisi Januari 2017 | 25

Tetrasiklin (Tetrasiklin). PHARMACON Jurnal Ilmiah Farmasi - UNSRAT Vol. 4 No. 3: 88-95.

[3] Khan, H.A., Ahmad, A., Mehboob, R. 2015. Nosocomial Infections and their Control Strategies. Asian Pac J Trop Biomed; 5(7): 509514.

[4] Kim, C.J., Kim, H.B., Oh, M.D., Kim, Y., Kim, A., Oh, S., Song, K., Kim, E.S., Cho, Y.K., Choi, Y.H., Park, J., Kim, B., Kim, N.J., Kim, K.H., Lee, E.J., Jun, J.B., Kim, Y.K., Kiem, S., Choi, H.J., Choo, E.J., Sohn, K., Lee, S., Chang, H.H., Bang, J.H., Lee, S.J., Lee, J.H., Park, S.Y., Jeon, M.H., Yun, N.R. 2014. The Burden of Nosocomial Staphylococcus aureus Bloodstream Infection in South Korea: a Prospective Hospital-Based Nation Wide Study. BMC Infectious Diseases, 14 (590) : 2-9.

[5] Mahalingam. R., Bharathidasan, R., Ambikapathy, V., Panneerselvam, A. 2011. Studies on Antibacterial Activity of some Medicinalplant Against Human Pathogenic Microorganism. Asian J. Plant Sci. Res., 2011, 1(3):86-90.

[6] Nair, R., Hanson, B.M., Kondratowicz, K., Dorjpurev, A., Davaadash, B., Enkhtuya, B., Tundev, O., Smith, T.C. 2013. Antimicrobial Resistance and Molecular Epidemiology of Staphylococcus Aureus From Ulaanbaatar, Mongolia. PeerJ : 2:19.

[7] Nazzaro, F., Fratianni, F., Martino L.D., Coppola, R., and Feo, V.D. 2013. Effect of Essential Oils on Pathogenic Bacteria. Pharmaceuticals. 6 : 1451-1474.

[8] Poongothai, P., Rajan, S. 2013. Antibacterial Properties of Mangifera indica Flower Extracts on Uropathogenic Escherichiacoli. Int.J.Curr.Microbiol.App.Sci. 2(12): 104-111.

[9] Rahman, M.M., Sheikh, M.M.I., Sharmin S.A., Islam, M.S., Rahman, M.A, M Rahman, M., and Alam, M.F. 2009. Antibacterial Activity of Leaf Juice and Extracts of Moringa oleifera Lam. Against some Human Pathogenic Bacteria. CMU. J. Nat. Sci.Vol. 8(2) : 219-227.
[10] Reygaert, W.C. 2016. Insights on the Antimicrobial Resistance Mechanisms of Bacteria. Advances in Clinical and Medical Microbiology. Volume 2 Issue 1 ACMM-2-005 : $1-11$.

[11] Rodloff, A., Bauer, T., Ewig, S., Kujath, P., Müller, E. 2008. Susceptible, Intermediate, and Resistant - The Intensity of Antibiotic Action. Dtsch Arztebl Int 105(39): 657-62.

[12] Shailemo, D.H.P., Kwaambwa, H.M., Schulz, M.K., Msagati, T.A.M. 2016. Antibacterial Activity of Moringa ovalifo and Moringa oleifera Methanol, N-Hexan and Water Seeds and Bark Extracts against Pathogens That Are Implicated in Water Borne Diseases. Green and Sustainable Chemistry. $6: 71-77$.

[13] Setiawan Ogi, Wahyuni N, Susila W.W, Rahayu A.D, Rostiawati T., 2014, Bidara Laut (Strychnos ligustrina Blume) syn. S. lucida R. Br: Sumber Bahan Obat Potensial di Nusa Tenggara Barat dan Bali. FORDA press. Bogor.

[14] Sudhira L., Rao, S.V., Kamakshamma, J. 2015. Phytochemical Screening, Antioxidant and Antibacterial Activity of Strychnos colubrina L.as an important Endangered Medicinal Species in Eastern Ghats. J. Pharm. Sci. \& Res. Vol. 7(5) : 242-247.

[15] Suriaman, E., Permana, A. S. H., Warman, M. 2016. Aktivitas Antibakteri Ekstrak Etanol Buah Mentimun (Cucumis sativus Linn) terhadap Salmonella typhi dan Bacillus cereus secara In Vitro. Stigma Journal of Science. 9 (1) $: 1-5$.

[16] Uwaezuoke, J.C., Aririatu, L.E. 2004. A Survey of Antibiotic Resistant Staphylococcus AureusStrains from Clinical Sources in Owerri. J. Appl. Sci. Environ. Mgt. Vol. 8 (1): 67 - 69. 